\title{
Revalidation and taxonomic revision of Teloneria Aczél (Diptera, Neriidae), with description of two new species
}

\author{
Tatiana A. SEPÚLVEDA ${ }^{1, *}$, Diego de S. SOUZA ${ }^{2}$, Angela ECHEVERRY ${ }^{3}$, \\ Luciane MARINONI ${ }^{4} \&$ Claudio J.B. de CARVALHO ${ }^{5}$ \\ ${ }^{1,2}$ Departamento de Entomologia, Museu Nacional, Universidade Federal do Rio de Janeiro, \\ MNRJ, Horto Botânico, Quinta da Boa Vista, São Cristóvão, \\ 20940-040, Rio de Janeiro, Rio de Janeiro, Brazil. \\ ${ }^{3}$ Grupo de Entomología, Instituto de Biología, Universidad de Antioquia, A.A. 1226, \\ Medellín, Colombia. \\ 4,5 Departamento de Zoologia, Universidade Federal do Paraná, Caixa Postal 19020, \\ 81531-980, Curitiba, Paraná, Brazil. \\ *Corresponding author: tatiana.sepulveda.villa@gmail.com \\ 2Email: diegosantanasouza@hotmail.com \\ ${ }^{3}$ Email: angela.mariae@hotmail.com \\ ${ }^{4}$ Email: 1marinoni@ufpr.br \\ ${ }^{5}$ Email: cjbcarva@ufpr.br

\begin{abstract}
${ }^{1}$ urn:1sid:zoobank.org:author:2A8F7FA7-E839-4AE5-B758-EC85AF844EC7
${ }^{2}$ urn:1sid:zoobank.org:author:AEFBD1DD-EB54-4604-B1A0-D87A55AEFB7F

${ }^{3}$ urn:lsid:zoobank.org:author:6F22C710-FB5E-4A68-B85E-41517E5BADE2

${ }^{4}$ urn:lsid:zoobank.org:author:B45CCAD0-081D-4589-B053-E207E7E4A880

${ }^{5}$ urn:1sid:zoobank.org:author:86DA58A2-152B-45F8-AACB-657FB50D3E62
\end{abstract}

\begin{abstract}
The genus Teloneria Aczél, 1954 is resurrected from synonymy with Chaetonerius Hendel, 1913 to include four species: Teloneria apicata (Edwards, 1919) comb. nov., Teloneria bimaculata (Edwards, 1919) comb. nov., Teloneria juceliae Sepúlveda \& Souza sp. nov. and Teloneria ladyae Sepúlveda \& Souza sp. nov. Lectotypes for Telostylus apicatus Edwards, 1919 and its junior synonym, Telostylinus apicalis Enderlein, 1922, and for Telostylinus ornatipennis Enderlein, 1922, junior synonym of Teloneria bimaculata comb. nov., are designated. An identification key to Chaetonerius, Telostylus Bigot, 1859 and Teloneria, with emphasis on the identification of the species of Teloneria, illustrations and distribution data are provided.
\end{abstract}

Keywords. Chaetonerius, Oriental Region, Nerioidea, new records, taxonomy.

Sepúlveda T.A., de Souza D.S., Echeverry A., Marinoni L. \& de Carvalho C.J.B. 2020. Revalidation and taxonomic revision of Teloneria Aczél (Diptera, Neriidae), with description of two new species. European Journal of Taxonomy 717: 70-89. https://doi.org/10.5852/ejt.2020.717.1099 


\section{Introduction}

Chaetonerius apicatus (Edwards, 1919) and Chaetonerius bimaculatus (Edwards, 1919) are Oriental species of Neriidae distributed across southeast Asia. The particular morphology of these species has made their classification controversial, with different authors placing them in Telostylus Bigot, 1859, Telostylinus Enderlein, 1922 or Chaetonerius Hendel, 1913 (Edwards 1919; Enderlein 1922; Hennig 1937).

Hennig (1937) expressed the difficulty of classifying these species among the known genera of Neriidae when, in the same work, he placed them provisionally in Telostylinus and included them in the identification key for Chaetonerius. Aczél (1954) proposed the genus Teloneria Aczél, 1954 to house these species, characterizing it by the following characters: arista brown, three dorsocentral setae and head almost as long as high, with the eye occupying a considerable part of its lateral surface. Subsequently, without providing any argumentation, Steyskal (1977) synonymized Teloneria under Chaetonerius.

Recent taxonomic reviews have shown that the morphology of C. apicatus and C. bimaculatus is fundamentally inconsistent with the diagnostic characters of Chaetonerius and Telostylus (Sepúlveda \& de Carvalho 2019; Sepúlveda et al. 2019), supporting Azcél's (1954) hypothesis that these species should be classified in an independent genus. Thus, in this paper, we review the morphology of C. apicatus and $C$. bimaculatus and revalidate the genus Teloneria to allocate these and other two species herein described as new to science: T. juceliae Sepúlveda \& Souza sp. nov. and T. ladyae Sepúlveda \& Souza sp. nov. Additionally, seeking to stabilize the names of the species in Teloneria, we designate lectotypes for T. apicata comb. nov. and T. bimaculata comb. nov. and their synonyms and, in order to clarify the separation of Teloneria from Chaetonerius and Telostylus, we provide a key for these genera, with emphasis on the identification of the species of Teloneria.

\section{Material and methods}

This study is based on material from the following institutions:

$\begin{array}{ll}\text { CSCA } & \text { California State Collection of Arthropods, Sacramento, CA, United States of } \\ \text { NHMUK } & =\text { America } \\ \text { TAUI } & =\text { Tel Aviv University, Tel Aviv, Israel } \\ \text { UCDC } & =\text { University of California, R.M. Bohart Museum of Entomology, Davis, CA, } \\ \text { ZMHB } & =\text { United States of America }\end{array}$

The type material of $C$. apicatus and $C$. bimaculatus was studied and both species were redescribed. Label information is provided for each specimen examined, followed by the depository institution along with an identification number, which is also included on the determination label pinned with each specimen. Information on labels of type material is written verbatim and each label is separated by double forward slashes ' $/ /$ '. Total length of the specimens is measured from the parafacial to the posterior margin of tergite 6. General morphological terminology follows Cumming \& Wood (2017) and terminology used to describe male genitalia follows Ovtshinnikova \& Galinskaya (2017).

Illustrations of genitalia were produced after removing the apical portion of the abdomen and clearing it in $10 \% \mathrm{KOH}$ overnight at room temperature. After examination, the genitalia were neutralized using acetic acid and stored in a glass microvial containing fresh glycerin, which was pinned with the corresponding dissected specimen. 
Photographs were made using a Leica DFC 500 digital camera mounted on a Leica MZ16 stereoscope and images were edited with the computer software Leica LAS 3D Viewer and LAS Montage ver. 4.7. New records are indicated by an asterisk in the 'Distribution' section of each redescription. The map with the geographic distribution of the species was generated using Google Earth ver. 7.1.1.1580 to obtain decimal coordinates and QGIS 3.10-A Coruña (QGIS Development Team 2019) was used to plot the distribution of the points.

\title{
Results
}

\author{
Class Insecta Linnaeus, 1758 \\ Order Diptera Linnaeus, 1758 \\ Suborder Brachycera Schiner, 1862 \\ Superfamily Nerioidea Hendel, 1916 \\ Family Neriidae Westwood, 1840
}

Genus Teloneria Aczél, 1954

Teloneria Aczél, 1954: 510.

\section{Type species}

Telostylinus apicalis Enderlein, 1922 (original designation) (= Telostylus apicatus Edwards, 1919).

\section{Remarks}

The genus Teloneria is restituted from synonymy with Chaetonerius based on the following distinctive features: i) arista brown with pubescence shorter at base and longer towards apex; ii) inner process of pedicel positioned at dorsal half of inner surface, with broad linear shape and rounded apex; iii) antennal base shiny and small but well-developed, visible laterally between the anterior margin of frons and parafacial; iv) parafacial, genal and postocular areas very narrow, with the eye occupying a considerable part of its lateral surface; v) posterior fronto-orbital seta positioned at mid length of the eye; vi) three well-developed and long dorsocentral setae (one presutural and two postsutural), and vii) the exclusive character of wing vein $\mathrm{A} 2$, ending abruptly before reaching the second third of the anal lobe. As the species of Teloneria were associated with Chaetonerius and Telostylus in the past, we redescribe the genus and provide a key to clarify the separation between the newly restituted genus and these genera.

\section{Redescription}

Small species with very long setae. Tegument shiny; pruinescence, when present, sparse.

HeAD (Fig. 1A-B). Pedicel with one dorso-apical and one ventro-apical outstanding setae. Scape slightly longer than width. Anterior fronto-orbital seta positioned near anterior margin of fronto-orbital plate. Vertex and occiput joining in a curve that follows from close to posterior margin of eye until postgena. Parafacial and gena running very close to eye margin from genal seta towards antennal base. Postgena convex and narrow, with black setulae near occipital foramen.

Thorax (Fig. 1C-D). Thoracic setae conspicuously long, measuring 1.5-2.0 times length of scutellum. Scapular seta absent. Postpronotal lobe as long as height and slightly protuberant. Scutellum sub-shiny and trapezoidal with rounded margins; apical scutellar seta slightly shorter than dorsocentral prescutellar seta. Anterior notopleural setae present. Katatergite slightly protruded. Katepisternum with one ventral seta. Basicosta with two setae. Femora cylindrical and conspicuously elongate. Anterior margin of mid femur with proximal row of 10-14 setae. Tibiae with row of dorsal short setae. 
AвDOMEn. Homogeneously colored. Syntergite $1+2$ with short and numerous setae in anterior half, followed by a bare medial area and posteriorly; with longer setae in lower density. Sternite 6 capeshaped, laterally elongate and narrower near lateral margin of tergite 6 . Syntergosternite 8 with 3-5 long setae in proximal half of dorsal surface. Epandrium cylindrical and elongate, measuring approximately 1.5-2.0 times length of syntergosternite 8; cercus and surstylus variable in length and shape (Fig. 2); pregonite bare.

\section{Species included}

Teloneria apicata (Edwards, 1919) comb. nov.

Teloneria bimaculata (Edwards, 1919) comb. nov.

Teloneria juceliae Sepúlveda \& Souza sp. nov.

Teloneria ladyae Sepúlveda \& Souza sp. nov.

Teloneria apicata (Edwards, 1919) comb. nov.

Figs 1A, C, 2A, 3A-B, 7J, N, 8G, J, 9

Telostylus apicatus Edwards, 1919: 53.

Telostylinus apicalis Enderlein, 1922: 143.

Telostylinus apicalis - Hennig 1937: 270 (key), 271 (notes), 279 (catalogue). — Steyskal 1977: 9 (synonymy).

Telostylus apicatus - Hennig 1937: 269 (catalogue). — Steyskal 1966: 5 (key). — Mello \& Ziegler 2012: 149 (type material).

Teloneria apicalis - Aczél 1954: 510 (type species); 1955: 30 (key, redescription), 36, fig. 6 (thorax), 40, figs $28-30$ (head).

Chaetonerius apicatus - Steyskal 1977: 9 (combination).

\section{Diagnosis}

Teloneria apicata and T. bimaculata can be differentiated from T. juceliae sp. nov. and T. ladyae sp. nov. by the general darker color and the inner vertical and outer vertical setae of almost the same length. All Teloneria species have the gena and postpronotal lobe yellow, but only T. apicata have the frontoorbital plate, occiput, mid coxa and femora black. Also, T. apicata and T. bimaculata bear a mostly black frontal vitta, with a small anterior area yellow. The head of $T$. apicata is at most slightly elongate and not evidently elongate as in T. bimaculata and T. juceliae sp. nov., and the anterior fronto-orbital seta is well-developed but less than half the length of the posterior fronto-orbital seta. Males of T. apicata bear an anteroventral row of long, spine-like setae.

\section{Material examined}

Lectotype of Telostylus apicatus Edwards, 1919 (here designated) THAILAND • +; "SYNTYPE [blue perimeter label] // Siam: Bulsit Besar. H. C. Robinson \& N. Annandale, 1916-21 //SYNTYPE, Telostylus apicatus Edwards, det. J. E. Chainey, 1995 //NHMUK010240951"; NHMUK (Fig. 3A).

Lectotype of Telostylinus apicalis Enderlein, 1922 (here designated) INDONESIA - O; "Ober-Langkat, Deli, Sumatra, 1894, M. U. de S. // Type [red label] // Telostylinus apicalis đ, Type Enderlein, Dr. Enderlein det. 1921 // Zool. Mus. Berlin // SYNTYPE, Telostylinus apicalis Enderlein, 1922, det. Mello \& Ziegler 2010 [red label]”; ZMHB (Fig. 3B). 


\section{Paralectotypes of Telostylus apicatus Edwards, 1919}

THAILAND • 1 q; "Siam: Bulsit Besar. H. C. Robinson \& N. Annandale, 1916-21// SYNTYPE, Telostylus apicatus Edwards, det. J. E. Chainey, 1995 // NHMUK010240952”; NHMUK.

INDONESIA • 1 ; ; "SYNTYPE [blue perimeter label] //TYPE, Telostylus apicatus Edw. [red perimeter label] // 1916. Scolak Daras, 65. W. Sumatra, 1914. (Robinson \& Kloss) // SYNTYPE, Telostylus apicatus Edwards, det. J. E. Chainey, 1995 // NHMUK010240950”; NHMUK.

Paralectotype of Telostylus apicalis Enderlein, 1922

INDONESIA • O; " "Ober-Langkat, Deli, Sumatra, 1894, M. U. de S. // Type [red label] // Telostylinus apicalis +, Type Enderlein, Dr. Enderlein det. 1921; Zool. Mus. Berlin // SYNTYPE, Telostylinus apicalis Enderlein, 1922, det. Mello \& Ziegler 2010 [red label]”; ZMHB.

Other material $(2 \hat{\partial} \hat{\partial}, 3$ 우 $)$

MALAYSIA • 1 đ (dissected); W Malaysia, Pahang, Bukit Tinggi forest; alt. 1300 ft; 26 Dec. 1972; A.E. Stubbs leg.; BMNH 1974-87; NHMUK 1822 • 1 \%; same collection data as for preceding; NHMUK 1626 - 1 ồ; Borneo, Sabah, Penampang District, Crocker Range, Kipandi Butterfly Park; 552'20" N,
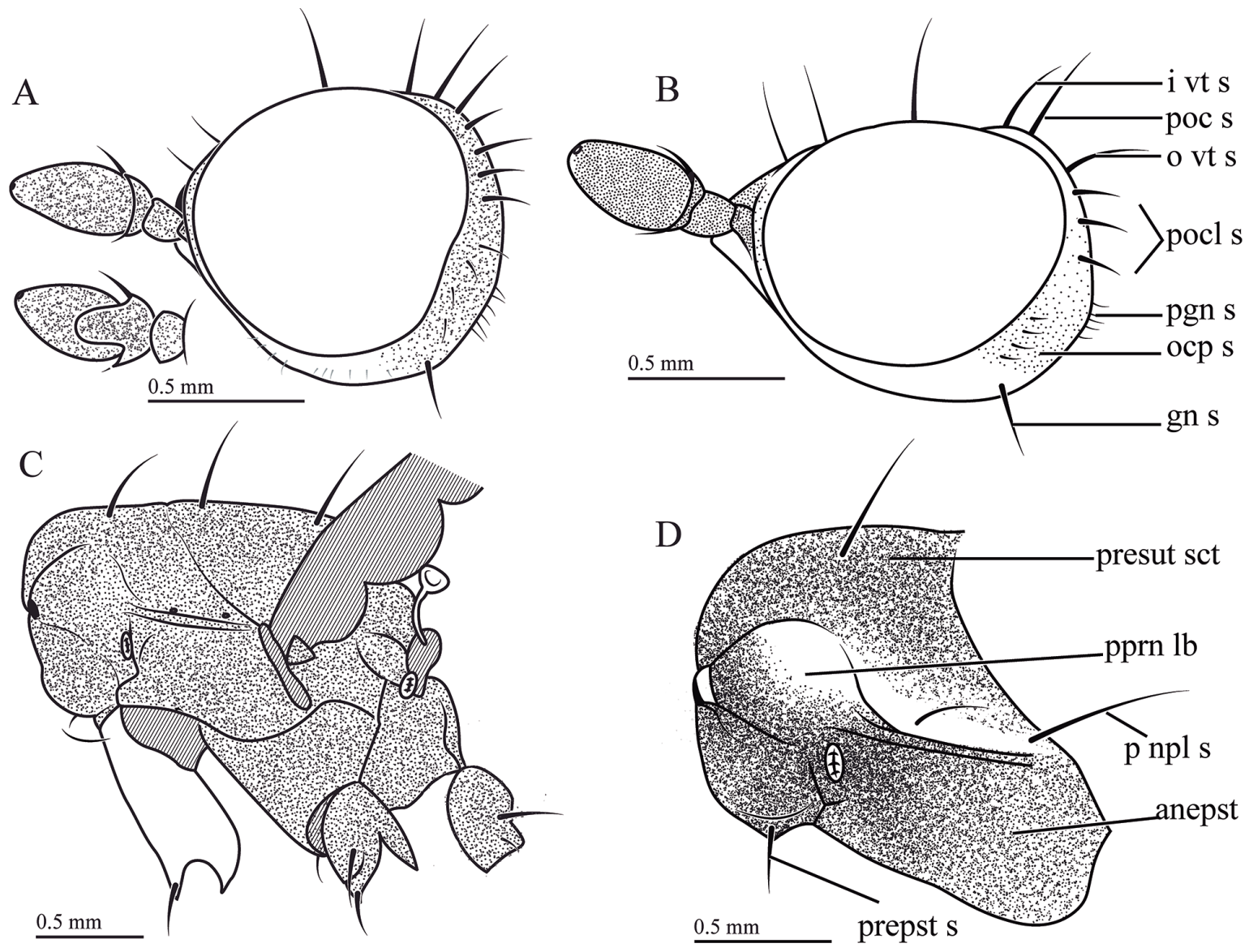

Fig. 1. Head and thorax in lateral view. A, C. Teloneria apicata (Edwards, 1919) comb. nov. (UCDC 1821). B, D. Teloneria bimaculata (Edwards, 1919) comb. nov. (Telostylinus ornatipennis, lectotype, + , ZMHB). Abbreviations: anepst $=$ anepisternum; gn $\mathrm{s}=$ genal seta; i vt $\mathrm{s}=$ inner vertical seta; ocp $\mathrm{s}=$

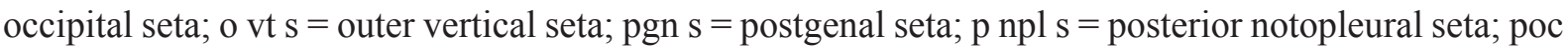
$\mathrm{s}=$ postocellar seta; pocl $\mathrm{s}=$ postocular seta; pprn $\mathrm{lb}=$ postpronotal lobe; prepst $\mathrm{s}=$ proepisternal seta; presut sct $=$ presutural scutum. 
116²14'53" E; alt. 720 m; 15 Oct. 2011; S. Gaimari and M. Hauser leg.; SDG11-15; CSCA 2807 • 1 \%; same collection data as for preceding; CSCA 2808 • 1 q; Borneo, Sarawak, S Gunung Buda, $64 \mathrm{~km} \mathrm{~S}$ of Limbang; 4¹2' N, 11456' E; 20 Dec. 1996; S.L. Heydon and S. Fung leg.; UCDC 1821.

\section{Redescription}

\section{Male}

MeAsurements. Body length 4.7-5.0 mm. Wing length 4.7-4.9 mm and width $1.2-1.5 \mathrm{~mm}$.

HEAD (Fig. 1A). First flagellomere ovate, narrowing on distal half, with broad apex (Fig. 7J). Anterior margin of frons slightly convex, projecting over small antennal base without surpassing anterior margin of parafacial (Fig. 7N). Fronto-orbital plate broad and shiny, sometimes with three or four fronto-orbital setae. Parafacial pale brown. Vertex and median occipital sclerite blackish-brown; outer vertical seta aligned with four postocular setae, almost of same size; row of $2-5$ occipital setae very short.

THORAX (Figs 1C; 8G). Dorsal longitudinal stripe of faint gray pruinescence; anterior notopleural seta subequal to posterior notopleural seta. Femora entirely brown; fore femur with several long anteroventral setae, diminishing in size distally and absent on distal third; ventro-apical surface of fore fourth tarsomere with four very thick setae.

ABdomen. Dark brown with several long setulae laterally on posterior half of syntergite $1+2$. Syntergosternite 8 protrudes basally, with two distal setae; epandrium twice the length of syntergosternite 8 , reaching posterior half of third segment ventrally; surstylus narrow linear; cercus broad linear, slightly narrowing on distal third, with broad round apex; length of cercus half length of epandrium and twice length of surstylus; distiphallus partially sclerotized, flattened and bifurcated, with distal and coiled membranous area bearing a sclerotized spike (Fig. 2A).

\section{Female}

Body length 4.6-5.6 mm. Fore femur and fourth tarsomere without thick ventral setae. Oviscape brown and shiny.

\section{Distribution}

Thailand, Malaysia* (Pahang, Sarawak), Indonesia (Sumatra).

\section{Remarks}

Despite being a syntype labeled as TYPE, we are hereby designating the male specimen in the most complete condition of preservation as lectotype to stabilize the taxonomic concept of this species and its name.

Teloneria bimaculata (Edwards, 1919) comb. nov.

Figs 1B, D, 2B, 3C-D, 6C, E, 7K, O, 8H, K, 9

Telostylus bimaculatus Edwards, 1919: 53.

Telostylinus ornatipennis Enderlein, 1922: 143

Telostylus bimaculatus - Hennig 1937: 270 (key), 279 (catalogue).

Teloneria bimaculatus - Aczél 1955: 30 (key).

Chaetonerius bimaculatus - Steyskal 1977: 9 (combination).

Telostylinus ornatipennis - Hennig 1937: 279 (synonymy). — Steyskal 1977: 10 (catalogue). — Mello \& Ziegler 2012 (type material). 

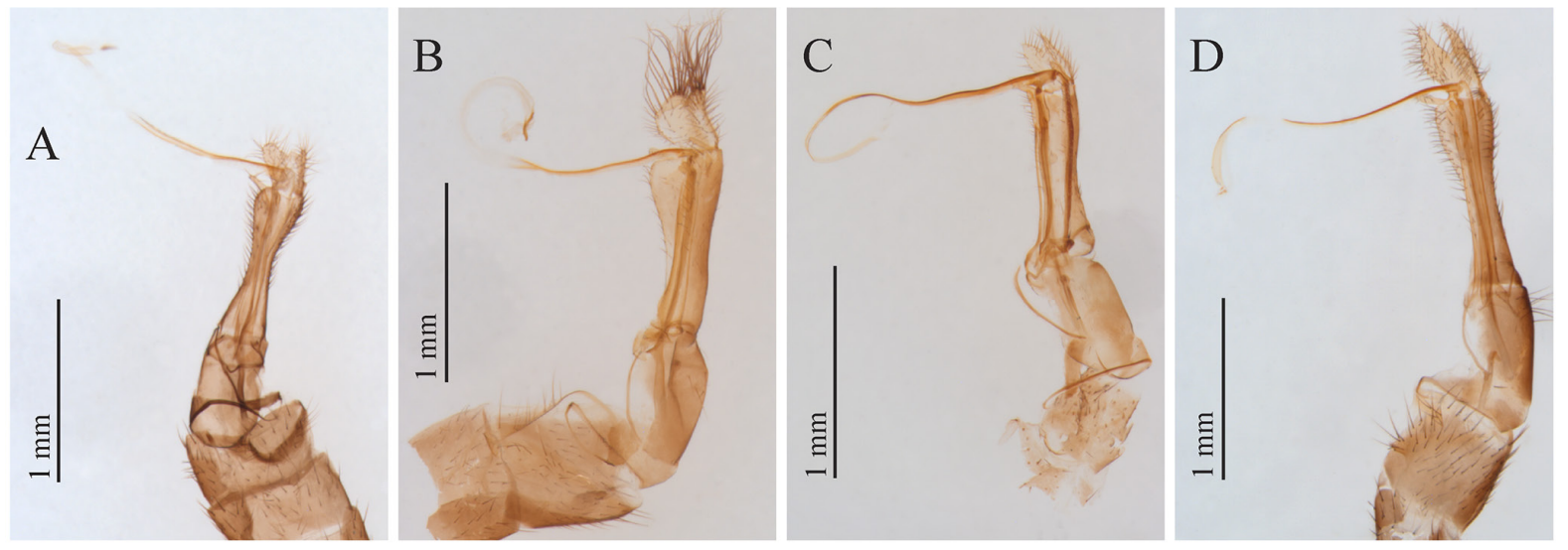

Fig. 2. Male genitalia. A. Teloneria apicata (Edwards, 1919) comb. nov. B. Teloneria bimaculata (Edwards, 1919) comb. nov. C. Teloneria juceliae Sepúlveda \& Souza sp. nov. D. Teloneria ladyae Sepúlveda \& Souza sp. nov.
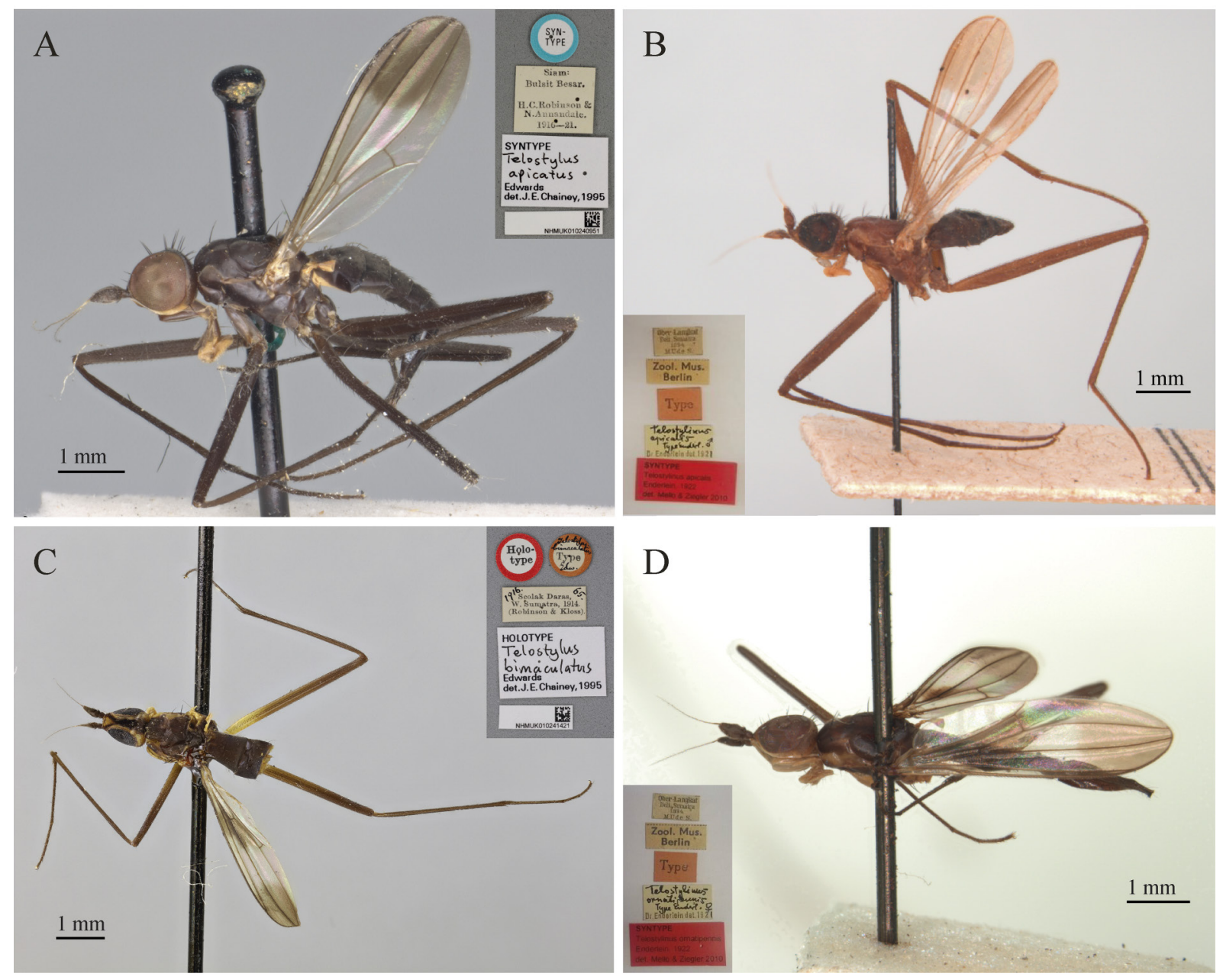

Fig. 3. Type material, habitus, lateral view. A. Telostylus apicatus Edwards, 1919, lectotype, q. B. Telostylinus apicalis Enderlein, 1922, lectotype, Ô. C. Telostylus bimaculatus Edwards, 1919, holotype, ㅇ. D. Telostylinus ornatipennis Enderlein, 1922, lectotype, ㅇ. 


\section{Diagnosis}

Teloneria bimaculata and T. apicata can be differentiated from T. juceliae sp. nov. and T. ladyae sp. nov. by the general darker color and the inner vertical and outer vertical setae being of almost the same length. Teloneria bimaculata and T. juceliae sp. nov. have the head elongate and mostly yellow, except for the black frontal vitta and pale brown ventral half of the occiput in the former. Other brown-colored structures that differentiate T. bimaculata from the yellow T. juceliae sp. nov. and T. ladyae sp. nov. are the proepisternum, femora (yellow only at base), and dorsal scutum and pleuron (yellow at postpronotal lobe). Exclusive characters of T. bimaculata include four fronto-orbital setae of almost the same length and the female wing cells $\mathrm{r} 1$ and $\mathrm{r} 2+3$ being basally infuscate.

\section{Material examined}

Holotype of Telostylus bimaculatus Edwards, 1919

INDONESIA • O; "HOLOTYPE [red perimeter label] // 1916. Scolak Daras, 65. W. Sumatra, 1914. (Robinson \& Kloss) // HOLOTYPE, Telostylus bimaculatus Edwards, det. J. E. Chainey, 1995 // NHMUK01241421"; NHMUK (Fig. 3C).

Lectotype of Telostylinus ornatipennis Enderlein, 1922 (here designated) INDONESIA • O; " 'Ober-Langkat, Deli, Sumatra, 1894, M. U. de S. // Type [red label] // Telostylinus ornatipennis, Type Enderlein ${ }_{+}$, Dr. Enderlein det. 1921 // Zool. Mus. Berlin // SYNTYPE, Telostylinus ornatipennis Enderlein, 1922, det. Mello \& Ziegler 2010 [red label]”; ZMHB (Fig. 3D).

Paralectotype of Telostylinus ornatipennis Enderlein, 1922

THAILAND • 1 क; “ "Ober-Langkat, Deli, Sumatra, 1894, M.U. de S. // Type [red label] // Telostylinus ornatipennis, Type Enderlein ${ }_{+}$, Dr. Enderlein det. 1921 // Zool. Mus. Berlin // SYNTYPE, Telostylinus ornatipennis Enderlein, 1922, det. Mello \& Ziegler 2010 [red label]”; ZMHB.

Other material $(4 \hat{\partial} \widehat{\partial}, 2$ $q$ +$)$

MALAYSIA • 1 \} \text { ; "Neriidae, Gen. Spec. [hand-written] // Siam: Talum. } 9 \text { Jan. } 1 9 0 2 \text { // H. O. Robinson } \& N. Annandale. 1916-21"; NHMUK 1899 • 1 đo; "Gentig Tea Estate, Gentig Sembah, forest 2000 feet // 24-27 Dec. 1972 // W. MALASYA: Selangor, A. E. Stubbs, BMNH 1974-87”; NHMUK 1827 • 1 क; same collection data as for preceding; NHMUK 2023.

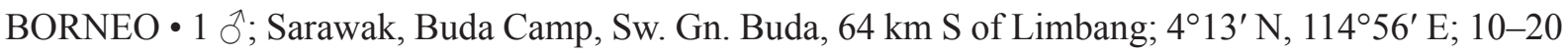
Nov. 1996; S.L. Heydon and S. Fung leg.; UCDC $1824 \cdot 1$ o ; same collection data as for preceding; UCDC $1825 \bullet 1$ क; same collection data as for preceding; UCDC 1826.

\section{Redescription}

Male

Measurements. Body length 5.3-6.3 mm. Wing length 4.5-5.9 mm and width $1.2-1.6 \mathrm{~mm}$.

Head (Figs 1B, 6C, E, 7O). First flagellomere ovate, narrowing on distal half, with broad apex (Fig. 7K). Anterior margin of frons convex, projecting over small antennal base without surpassing anterior margin of parafacial (or at most surpassing it very discreetly). Fronto-orbital plate broad and shiny. Parafacial pale brown to yellow. Vertex blackish-brown and median occipital sclerite paler; outer vertical seta aligned with 2-4 postocular setae of almost same length; row of 2-4 very short and hair-like occipital setae.

THORAX (Figs 1D, 8H). Dorsally brown or pale brown; dorsal longitudinal stripe of faint gray pruinescence; anterior notopleural seta subequal to posterior notopleural seta. Fore and mid coxae yellow, hind coxa brown. Femora brown with yellow base; fore femur without long anteroventral setae; fore tarsomeres with ventral row of short thick setae. 
AвDOMEn. Dark brown, with several long setulaelaterally on posterior half of syntergite $1+2$. Syntergosternite 8 with three median setae; epandrium 1.5-2.0 times as long as syntergosternite 8 , reaching anterior half of third segment ventrally; distal margin of epandrium extended laterally; surstylus narrow linear; cercus broad and spatulate; length of cercus $1 / 2$ to $2 / 3$ length of epandrium and three times length of surstylus; distal margin of cercus with conspicuously long and thick setae; distiphallus partially sclerotized, with median membranous area distally bifurcated in a sclerotized spike and a membranous coiled up tube (Fig. 2B).

\section{Female}

Body length 4.9-5.5 mm. Fore femur without strong ventral setae; tarsomeres without thick ventral setae. Oviscape brown and shiny.

\section{Distribution}

Taiwan, Malaysia* (Pahang, Selangor, Sarawak), Indonesia (Sumatra).

\section{Remarks}

The abdomen of the holotype is lost. However, the basally infuscate wing cells $r_{1}$ and $r_{2+3}$ indicate that it is a female specimen. The cercus morphologically differentiated varies in length among specimens and presents conspicuously long distal setae. According to Van Steenis \& Hippa (2012), the material labeled as 'Siam: Talum' by O. Robinson and N. Annandale (9 Jan. 1902) was collected in Lubok, Tamang, Pahang, F.M.S.
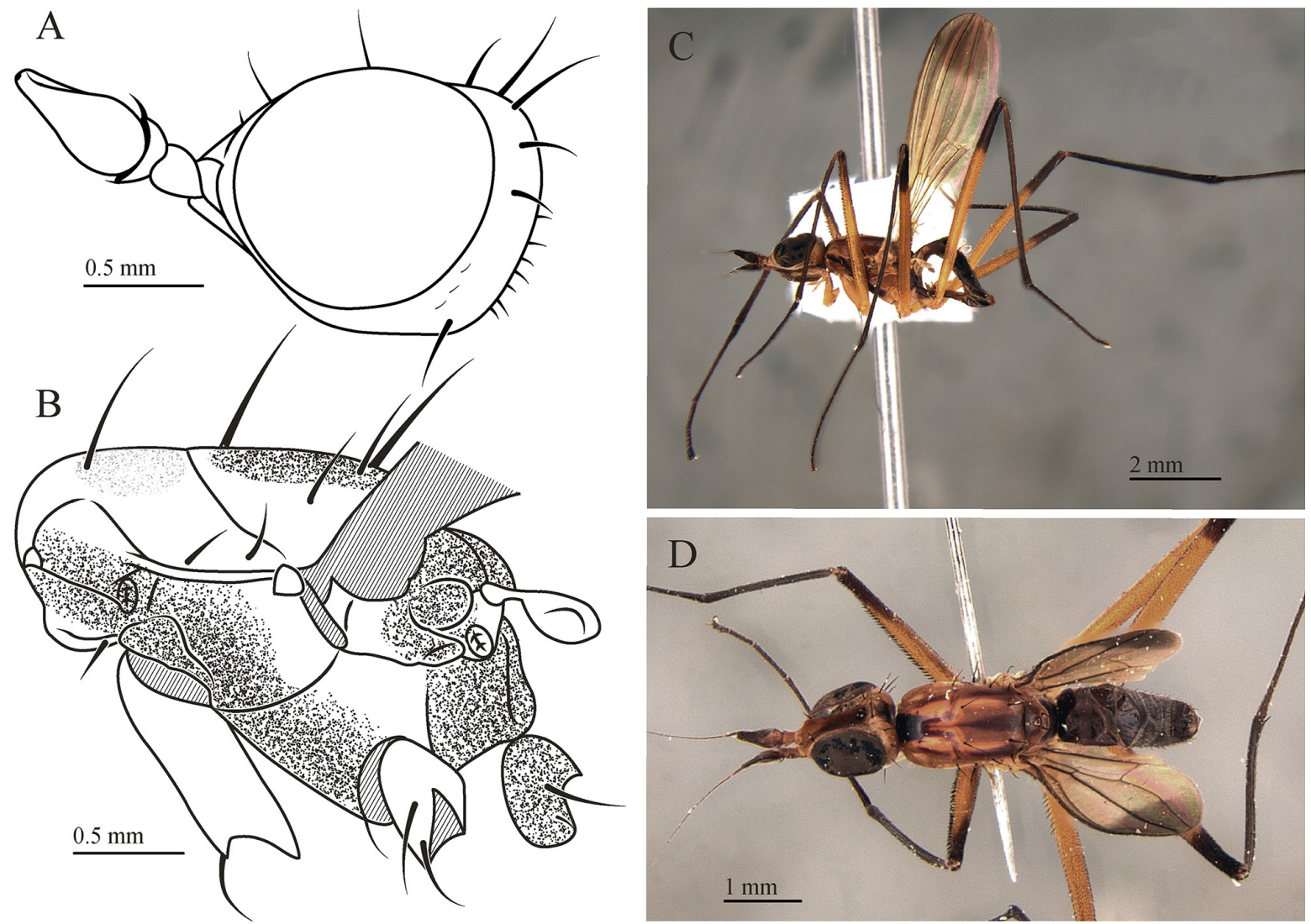

Fig. 4. Teloneria juceliae Sepúlveda \& Souza sp. nov. A. Head, lateral view,, , paratype (TAUI 1003). B. Thorax, lateral view, $\widehat{\jmath}$, holotype (TAUI 1004). C. Habitus, lateral view, holotype, (TAUI 1004). D. Habitus, dorsal view, holotype (TAUI 1004). 
Teloneria juceliae Sepúlveda \& Souza sp. nov. urn:Isid:zoobank.org:act:883AAEBF-A213-4BF0-A4D7-680436FB37C3

Figs $2 \mathrm{C}, 4 \mathrm{~A}-\mathrm{D}, 9$

\section{Diagnosis}

Teloneria juceliae sp. nov. and T. bimaculata have the head elongate and mostly yellow, except for the black frontal vitta and pale brown ventral half of occiput of the latter. Teloneria juceliae sp. nov. and T. ladyae sp. nov. are very similar in general color, both having the thorax yellowish-brown subshiny with dorsal brown and yellow areas; postpronotal lobe, notopleura, anepisternum, anepimeron and katepisternum partially yellow; and femora yellow with distal fourth black. These two species also have the inner vertical seta one third or more shorter than the length of the outer vertical seta. Exclusive characters of $T$. juceliae sp. nov. include having the first flagellomere pear-shaped with the distal half slightly twisted up (Fig. 4A), two well-developed fronto-orbital setae, a broad median dark brown line on the dorsal scutum (Fig. 4D) and the male fore femur with three rows of short and thick ventral setae.

\section{Etymology}

The specific epithet 'juceliae' is dedicated to D.S. Souza's mother, Jucelia Pereira de Santana Souza.

\section{Material examined}

\section{Holotype}

THAILAND • ${ }^{\wedge}$; Mae Hong Son Prov., Tham Pla NP, Pha Sua waterfall; alt. 350 m; $19^{\circ} 29.45^{\prime}$ N, 9757.44' E; 14 May 2004; Ilan Yarom leg.; SMNH-TAUI 205885; TAUI 1004 (Fig. 4C-D).

Paratypes $(10 \hat{\partial} \hat{\partial}, 4$ 우 $)$

INDIA • 1 Oें; "Meghalaya, Nonghpoh Forest; 7 Nov. 2002; A. FREIDBERG; SMNH-TAUI 205837"; TAUI $672 \bullet 1 \delta^{\lambda}$; same collection data as for preceding but SMNH-TAUI 205834; TAUI $675 \bullet 1$ ' collection data as for preceding but SMNH-TAUI 205829; TAUI $681 \bullet 1$; ; same collection data as for preceding but SMNH-TAUI 205835; TAUI 674.

THAILAND $1 \hat{\partial}$ (dissected); same collection data as for holotype; SMNH-TAUI 205884; TAUI 1005

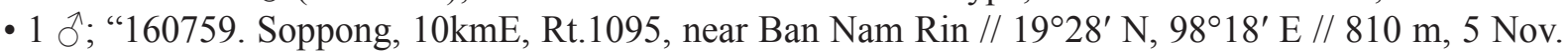

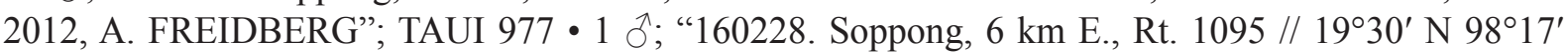
E // 700 m, 1-2 Nov. 2012; A. FREIDBERG”; TAUI 998 • 1 ऽ; same collection data as for holotype; 160340; TAUI $994 \bullet 1$; ; same collection data as for holotype; 162316 ; TAUI $996 \bullet 1$ \&; same collection data as for holotype; 160230; TAUI $997 \bullet 1$ \%; same collection data as for holotype; 160338; TAUI 985 - 1 q; "NW: Soppong, 8 kmS Rt. 1095, near Ban Man Rim // 28-30 Oct. 2002 // A. FREIDBERG, SMNH-TAUI 205970"; TAUI 1022 • 1 సं; "S. TakuaPa, Rt. 401 // 21 Oct. 1993 // F: KAPLAN \& A. FREIDBERG // SMNH-TAUI 205886"; TAUI 1003 • 1 đ ; "S. TakuaPa, Rt. 401 // 21 Oct. 1993 // F: KAPLAN \& A. FREIDBERG // SMNH-TAUI 205971"; TAUI 1023.

\section{Description}

\section{Male (holotype)}

Measurements. Body length $5.3 \mathrm{~mm}$. Wing length $5.2 \mathrm{~mm}$ and width $1.3 \mathrm{~mm}$.

HEAD (Fig. 4A). Anterior margin of frons straight; anterior fronto-orbital seta absent; middle fronto-orbital seta positioned near anterior margin of eye and as long as inner vertical seta; posterior fronto-orbital seta lost; outer vertical seta aligned with two subequal postocular setae; occipital setae inconspicuous.

Thorax (Fig. 4B). Sub-shiny and partially brown with yellow areas; broad median presutural dark brown line, medially divided near transverse suture; broad median brown postsutural line narrow near 
transverse suture, widening toward scutellum; scutellum brown dorsally and yellow laterally; anterior notopleural seta subequal to posterior notopleural seta; proepisternum yellow; ventral katepisternal seta hair-like and short. Fore and mid coxae yellow, hind coxa brown. Femora yellow with dark brown distal fourth, slightly paler on fore femur; fore tarsomeres without ventral setae; mid tibia cylindrical and thin; mid tarsomeres without ventral setae; hind trochanter without ventral patch of setulae.

ABdomen. Dark brown with several long setulae laterally on posterior half of syntergite $1+2$. Syntergosternite 8 not protruded basally and without marginal setae; epandrium only slightly longer than syntergosternite 8 , reaching anterior half of third segment ventrally; surstylus narrow linear; cercus broad linear, narrowing distally; length of cercus half length of epandrium and $2 / 3$ length of surstylus (Fig. 2C).

\section{Variation (males)}

Body length 4.6-6.6 mm. Wing length 5.2-6.5 mm and width $1.3-1.7 \mathrm{~mm}$. Inner process of pedicel broad linear to slightly triangular. Anterior margin of frons straight to slightly convex; posterior frontoorbital seta longer than inner vertical seta; postocular setae vary from three long setae to one short plus three long setae or one short seta plus two long setae. Yellow parts of body slightly darker and dorsal longitudinal lines of thorax vary in intensity, especially on anterior half, where these can be yellow to black. Proepisternum brown. Specimens from India (TAUI 674, 681, 672,-675) and two from Thailand (TAUI 1023, 1003) with thorax and pleuron mostly brown. Distiphallus partially sclerotized and flattened, with distal half divided by median membranous area and apex branched in two short membranous spikes.

\section{Female}

Body length 4.5-6.3 mm. Ventral katepisternal seta inconspicuous to absent in most females. Fore femur without ventral setae. Oviscape shiny, with dorsal line brown and laterally yellow to entirely brown.

\section{Distribution}

India, Thailand.

Teloneria ladyae Sepúlveda \& Souza sp. nov. urn:1sid:zoobank.org:act:F91D5FEE-A38F-4EC8-8E00-D112A4A1657A

Figs $2 \mathrm{D}, 5 \mathrm{~A}-\mathrm{D}, 9$

\section{Diagnosis}

Teloneria ladyae sp. nov. and T. juceliae sp. nov. are very similar in general color, both with thorax yellowish-brown sub-shiny with dorsal brown and yellow areas; postpronotal lobe, notopleura, anepisternum, anepimeron and katepisternum partially yellow; and femora yellow with distal fourth black. These species also bear an inner vertical seta one third or more shorter than the length of the outer vertical seta. Exclusive characters of T. ladyae sp. nov. include anterior margin of frons very convex, three well-developed fronto-orbital setae, hind trochanter with ventral patch of setulae and thorax mostly yellow, with two suprahumeral dark brown spots and one presutural median brown line. Within Neriidae, T. ladyae sp. nov. is the only species in which males bear strong mid legs, represented in the mid tibia thickening distally and mid tarsomeres with ventral setae.

\section{Etymology}

The specific epithet 'ladyae' is dedicated to T.A. Sepúlveda's mother, Luz Lady Villa Toro. 


\section{Material examined}

\section{Holotype}

MALAYSIA - Õ; "W. Malaysia, Selangor, Gentig Tea Estate, Gentig Sembah, forest 2000 feet, 24-27 Dec. 1972 // A. E. Stubbs // BMNH 1974-87”; NHMUK 1898 (Fig. 5B, D).

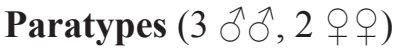

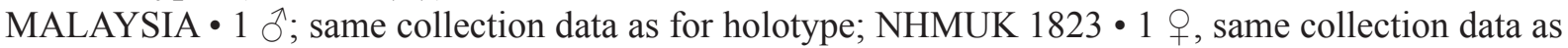
for holotype; NHMUK 1629.

THAILAND • 1 đ; "'S. Khao Lak 100, Km. N. Phuket, 19 Oct. 1993, F. KAPLAN \& A. FRIEDBERG // SMNH-TAUI 205845"; TAUI 666 • 1 万’; same collection data as for preceding; SMNH-TAUI 205846; TAUI $665 \bullet 1$ q; "South Ton Nga Chase N.P. 20 km SW Hat Yai // 20-24 Oct. 2002, A. FREIDBERG // SMNH-TAUI 205965"; TAUI 1015.

\section{Description}

Male (holotype)

MeAsurement. Body length $6.3 \mathrm{~mm}$. Wing length $5.7 \mathrm{~mm}$ and width $1.4 \mathrm{~mm}$.

HeAd (Fig. 5A). Rounded. First flagellomere ovate, with acute apex. Anterior margin of frons projecting over small antennal bases and between antennae, surpassing anterior margin of parafacial; outer vertical seta aligned with three subequal postocular setae; occipital setae very thin.
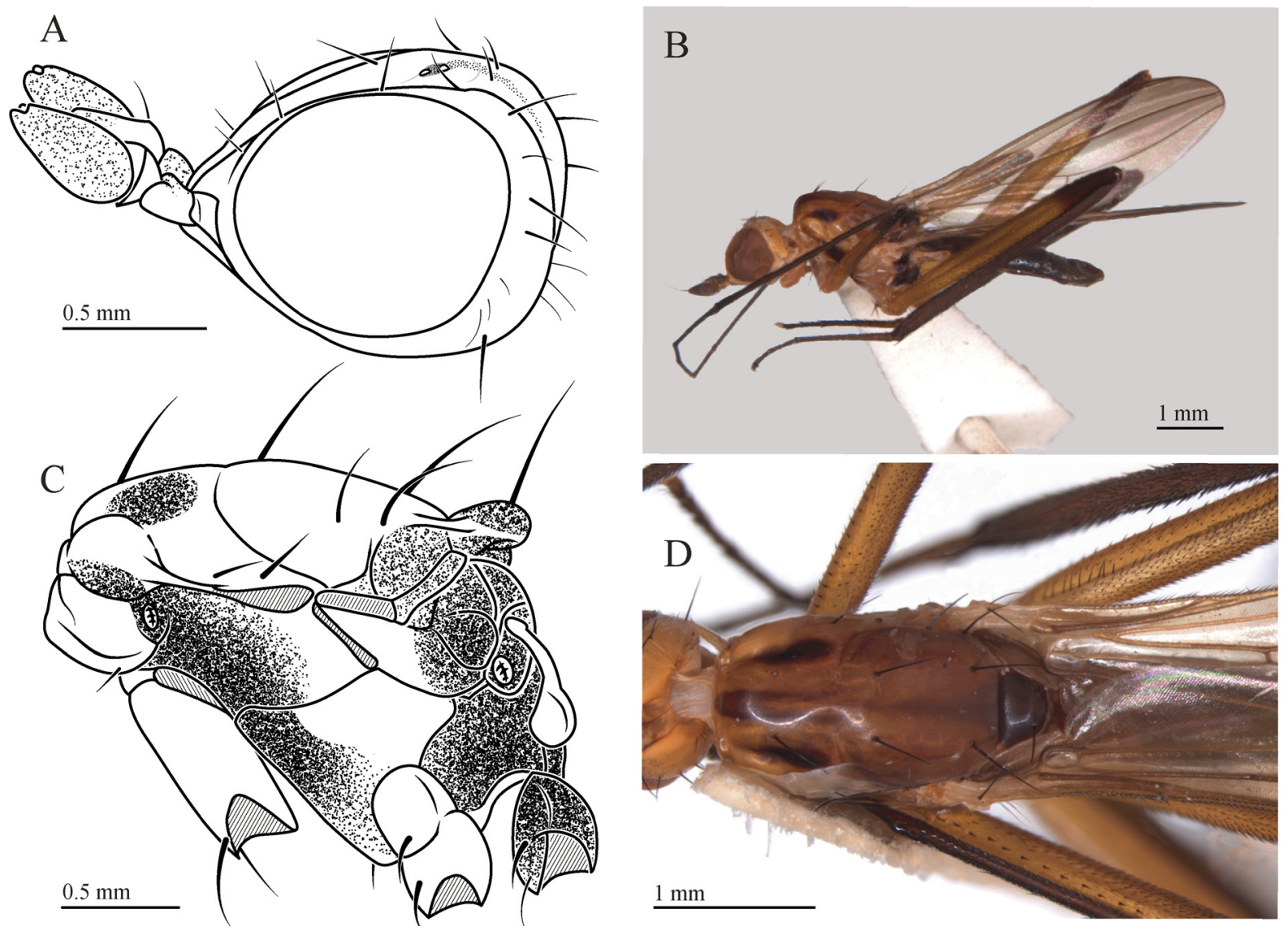

Fig. 5. Teloneria ladyae Sepúlveda \& Souza sp. nov., holotype (NHMUK 1898). A. Head, lateral view. B. Thorax, lateral view. C. Habitus, lateral view. D. Habitus, dorsal view. 

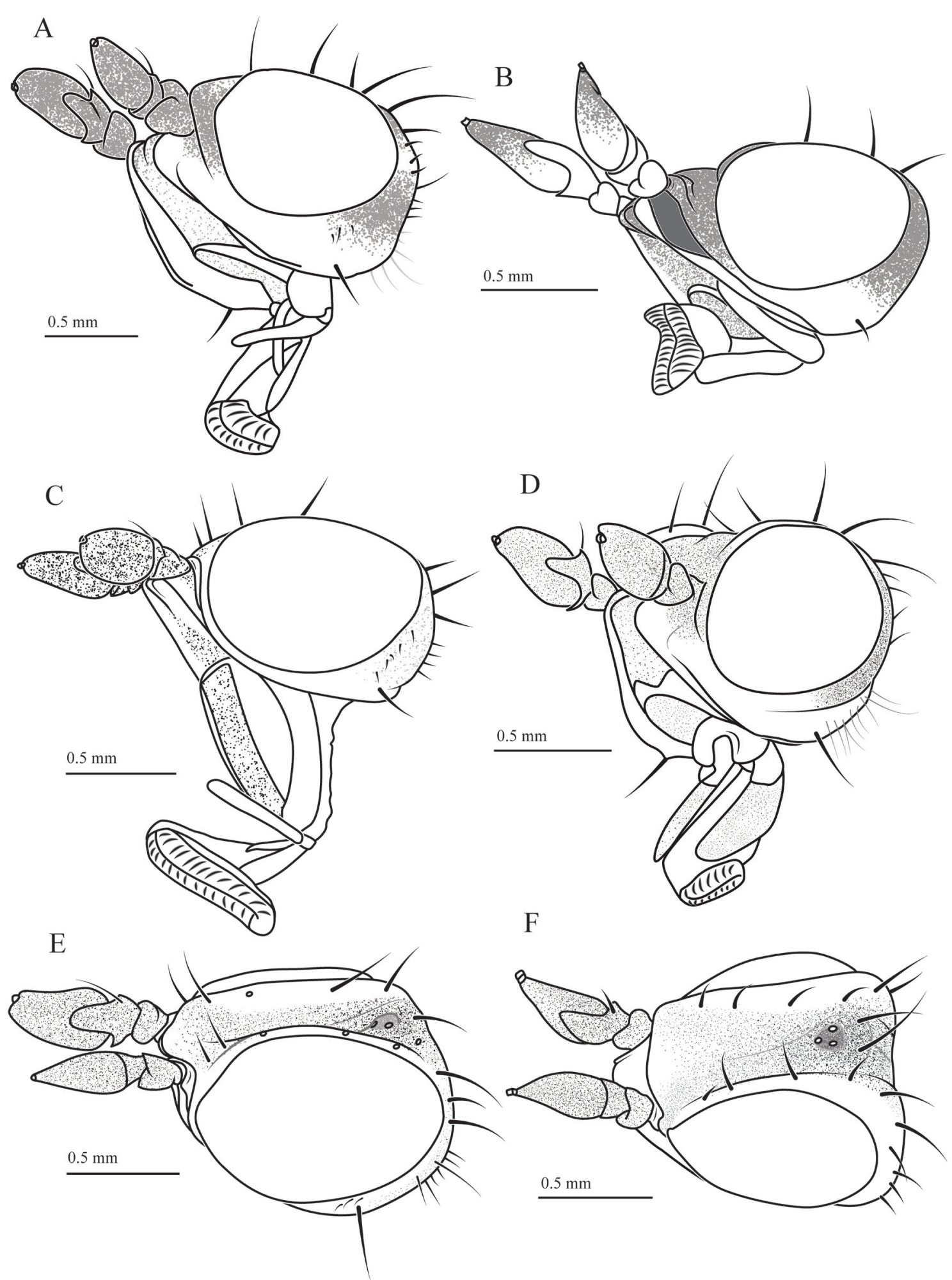

$\mathrm{F}$

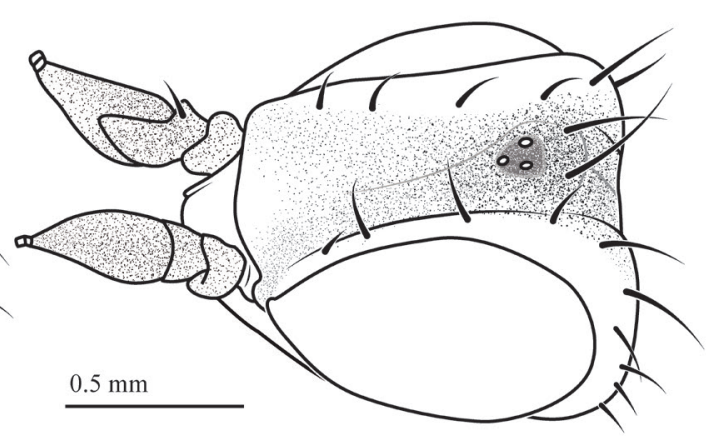

Fig. 6. Head in lateral view. A. Chaetonerius nolae Barraclough, 1993 (NHMUK 2804). B. Telostylus niger Bezzi, 1913 (NHMUK 1919). C. Teloneria bimaculata (Edwards, 1919) (NHMUK 2023). D. Chaetonerius inermis (Schiner, 1868) (NHMUK 1828). E. Teloneria bimaculata (NHMUK 2023). F. Chaetonerius inermis (NHMUK 1828). 
Thorax (Fig. 5C). Dorsal median brown line very pale, scutellum dark brown dorsally and yellow laterally; anterior notopleural seta subequal to posterior notopleural seta. Proepistermun yellow. Ventral katepisternal seta hair-like and short. Fore and mid coxae yellow, hind coxa brown. Femora yellow with brown distal fourth, slightly paler on fore femur; fore femur without ventral rows of setae; fore tarsomeres without ventral setae.

AвDOMEn. Dark brown except yellow lateral of syntergite $1+2$ at proximal half; syntergite $1+2$ with several long setulae laterally on posterior half. Syntergosternite 8 protruding basally and dorsally, with seven setae; epandrium only slightly longer than syntergosternite 8 , reaching anterior half of

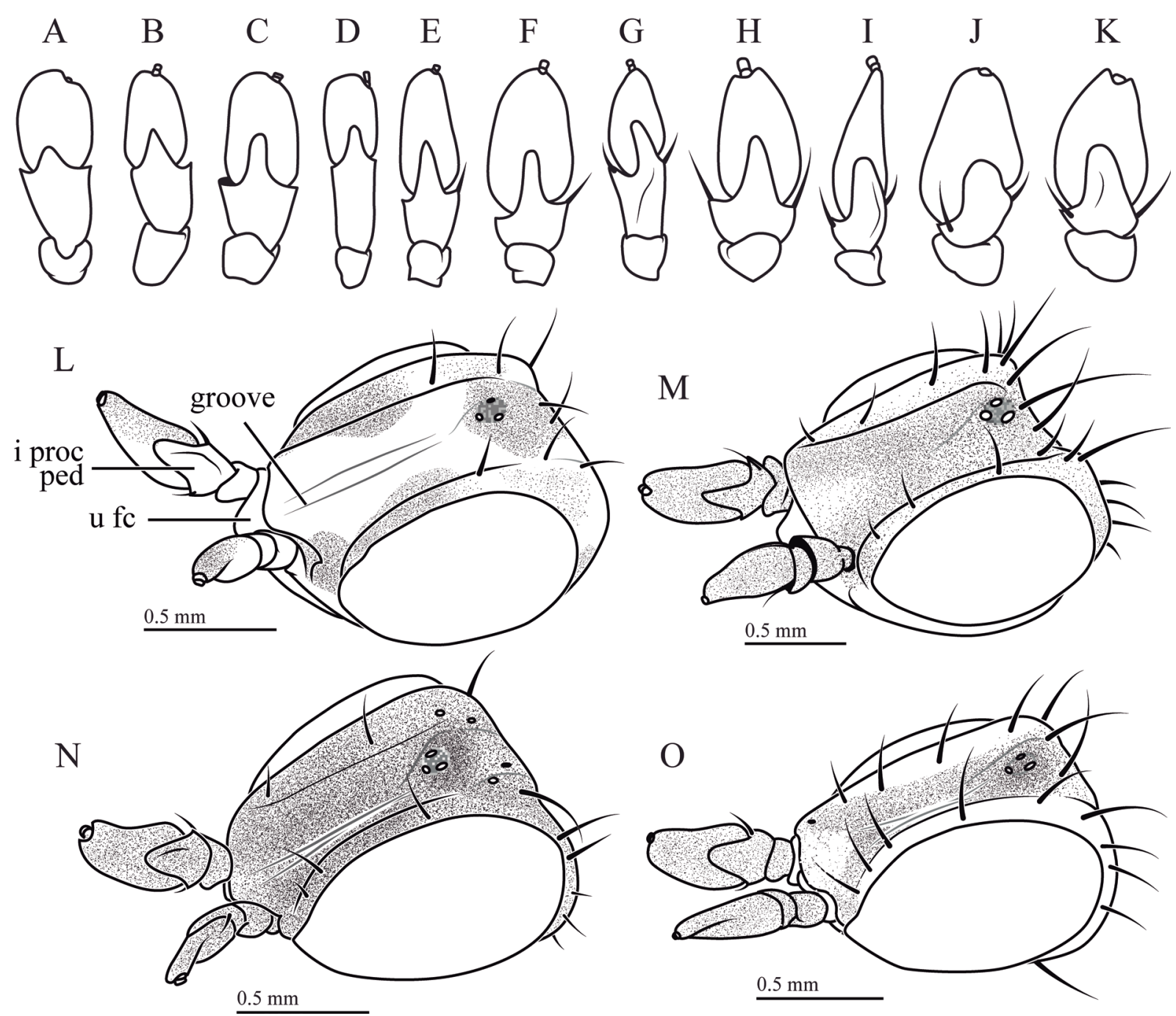

Fig. 7. Inner margin of antenna and head in lateral view. A. Nerius czernyi Aczél, 1961. B. Antillonerius cinereus (Röder, 1885). C. Eoneria blanchardi Aczél, 1951. D. Cerantichir enderleini Hennig, 1937. E. Glyphidops bullatus (Enderlein, 1922). F. Glyphidops durus (Cresson, 1926). G. Indonesicesa annulipes (Doleschall, 1857). H. Chaetonerius claricoxa Enderlein, 1922. I. Telostylus philippinensis Cresson, 1926. J. Teloneria apicata (Edwards, 1919) comb. nov. K. Teloneria bimaculata (Edwards, 1919) comb. nov. L. Telostylus marshalli Sepúlveda \& de Carvalho, 2019 (NHMUK 1179). M. Chaetonerius claricoxa (TAUI 895). N. Teloneria apicata comb. nov. (UCDC 1821). O. Teloneria bimaculata comb. nov. (ZMHB). Abbreviations: i proc ped $=$ inner process of pedicel; $\mathrm{u} \mathrm{fc}=$ upper face. 
third segment ventrally; surstylus narrow linear; cercus broad linear, tapering distally toward inner margin; length of cercus half length of epandrium and twice length of surstylus (Fig. 2D).

\section{Variation (males)}

Body length 4.9-6.32 $\mathrm{mm}$. Wing length 5.4-6.0 mm and width 1.2-1.6 mm. Head dark yellow. Anterior margin of frons very to slightly convex. Thorax with brownish-yellow longitudinal lines dorsally. One

A

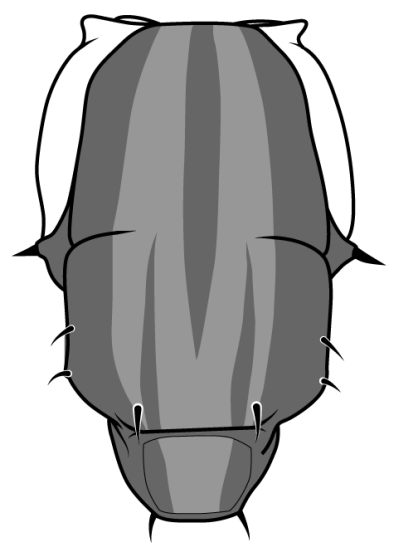

$1 \mathrm{~mm}$

$\mathrm{E}$

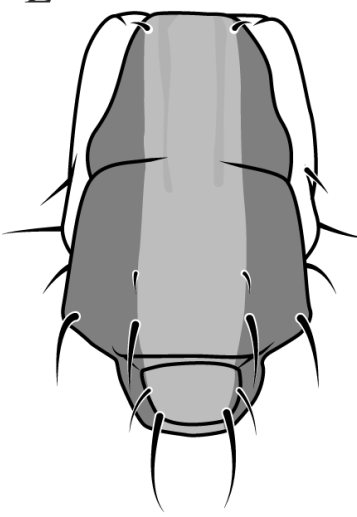

$1 \mathrm{~mm}$
$\mathrm{B}$

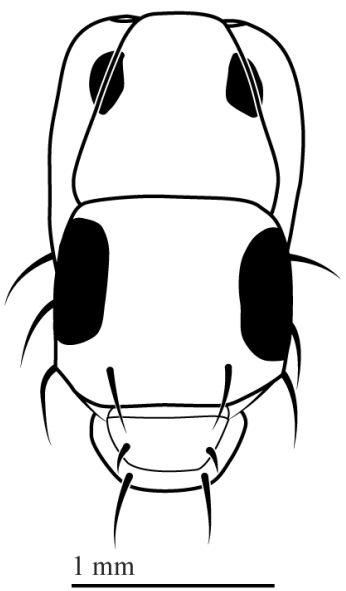

$\mathrm{F}$

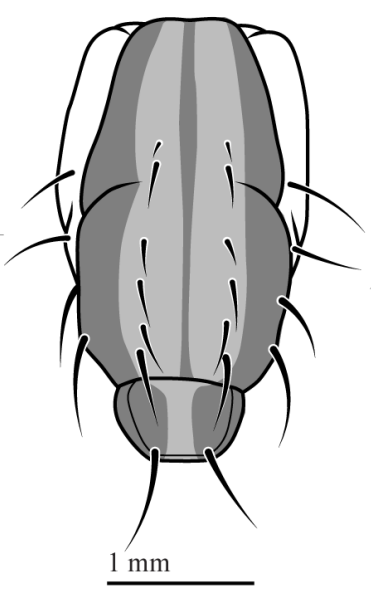

$\mathrm{C}$

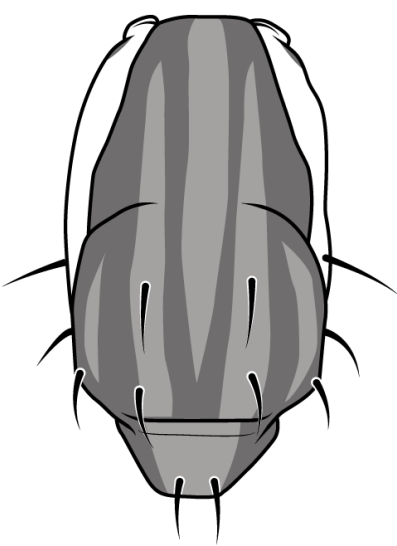

$1 \mathrm{~mm}$

$\mathrm{G}$

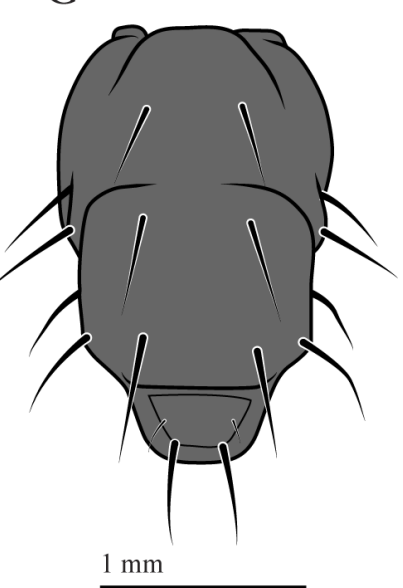

D

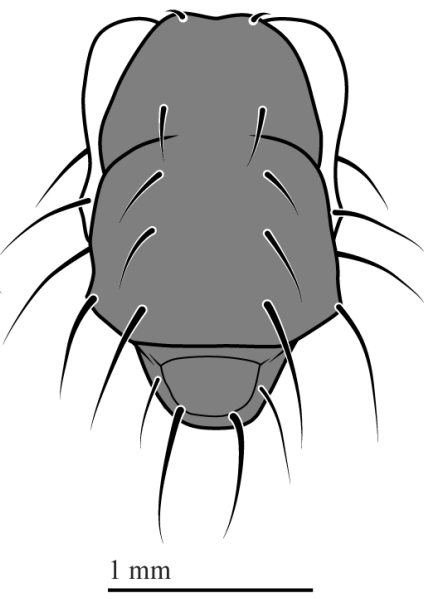

$\mathrm{H}$

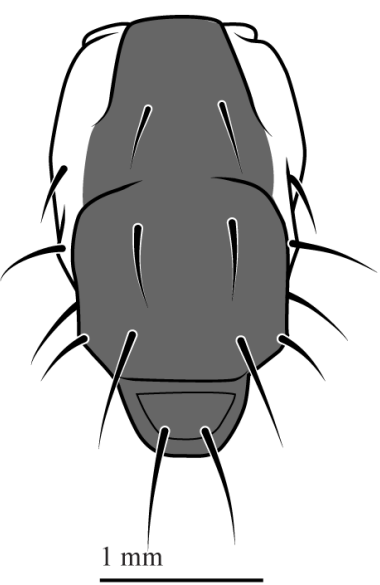

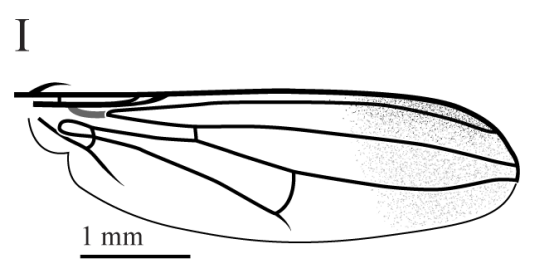

$\mathrm{J}$

$\mathrm{K}$
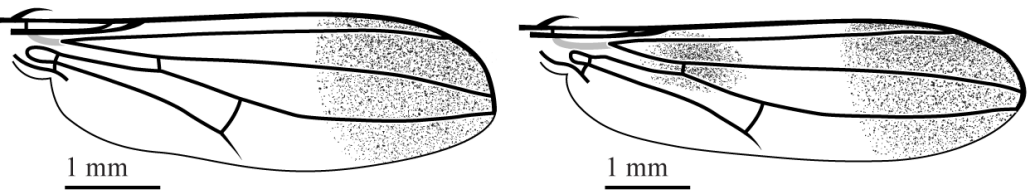

Fig. 8. Thorax in dorsal view and wing. A. Loxozus cornutus (Walker, 1853). B. Telostylus philippinensis Cresson, 1926. C. Derocephalus angusticollis Cresson, 1926. D. Chaetonerius claricoxa Enderlein, 1922. E. Chaetonerius latifemur Enderlein, 1922. F. Eoneria blanchardi Aczél, 1951. G. Teloneria apicata (Edwards, 1919) comb. nov. H. Teloneria bimaculata (Edwards, 1919) comb. nov. I. Telostylus marshalli Sepúlvesa \& de Carvalho, 2019 (NHMUK 1179). J. Teloneria apicata comb. nov. (UCDC 1821). K. Teloneria bimaculata comb. nov. (ZMHB). 
male from Selangor, Malaysia (NHMUK 1823) with anterior fronto-orbital seta longer than average and two ventral lines of short, spine-like setae on fore femur. Distiphallus partially sclerotized, with median membranous area followed by a sclerotized and flattened, coiled up distal part and apex with sclerotized spikes.

\section{Female}

Body length 4.4-5.9 mm. Thorax and legs darker. Mid tibia only slightly broader than fore tibia; hind trochanter without ventral patch of setulae. Oviscape entirely brown.

\section{Distribution}

Thailand, Malaysia (Selangor).

\section{Key to Chaetonerius, Telostylus and Teloneria, with emphasis on the identification of the species of Teloneria}

1. One or two postsutural dorsocentral setae (Figs 8B, G-H). Frontal vitta with a median longitudinal groove (Fig. 7L, N-O). Tegument shiny, mostly yellow or partially to entirely brown (Fig. 3). Abdomen homogeneously colored. Wing infuscate on distal third (Fig. 8I-K)

- Four postsutural dorsocentral setae (Fig. 8D). Frontal vitta without median longitudinal groove (Fig. 7M). Tegument opaque, brown and partially yellow to entirely brown. Abdomen with one dorsomedian yellow line. Wing slightly infuscate around meeting point of veins $\mathrm{R} 2+3$ and $\mathrm{C}$

2. Presutural dorsocentral seta absent and one pair of postsutural dorsocentral setae present (Fig. 8B). Postocullar setae absent (Fig. 7L). Transverse suture complete. Antennal base with membranous extension of upper face positioned dorsally Telostylus Bigot, 1859

- One pair of presutural and two pairs of postsutual setae present (Fig. 8G, K). Postocular setae welldeveloped (Fig. 7N-O). Transverse suture incomplete, vanishing medially on dorsal surface of scutum. Antennal base without dorsal membranous area 3... Teloneria Aczél, 1954

3. Postpronotal lobe and notopleura brown to pale brown (Fig. 3A). Fronto-orbital plate entirely black. Head around eye brown, only yellow near gena; occiput entirely brown Teloneria apicata (Edwards), 1919 comb. nov.

- Postpronotal lobe and notopleura pale brown to yellow (Fig. 3D). Fronto-orbital plate at least partially to entirely yellow (Fig. 3C). Head around eye mostly to entirely yellow; occiput pale brown or yellow on dorsal half

4. Frontal vitta mostly black, with a yellow spot on anterior third. Anepisternum, anepimeron and katepisternum brown ....

Teloneria bimaculata (Edwards)

- Frontal vitta pale brown or yellow and ocellar triangle black. Anepisternum, anepimeron and katepisternum partially yellow (Fig. 4C)

5. Anterior margin of frons straight to slightly convex, not projected between antennal bases. First flagellomere pear-shaped with distal half slightly twisted up (Fig. 4A). Scutum with median brown to black broad line from anterior margin to scutoscutellar suture, interrupted on transverse suture by a median yellow area; presutural and postsutural scutum laterally with brown longitudinal lines (Fig. 4D) Teloneria juceliae Sepúlveda \& Souza sp. nov.

- Anterior margin of frons strongly convex (V-shaped) and projected between antennal bases. First flagellomere ovate (Fig. 5A). Scutum with pale brownish median line on presutural scutum; presutural scutum with dark brown intra-alar spot and postsutural scutum laterally without brown lines (Fig. 5D) Teloneria ladyae Sepúlveda \& Souza sp. nov. 


\section{Discussion}

\section{Main features that differentiate Teloneria from other genera of Neriidae}

\section{Arista}

The arista in Teloneria is apically brown, with shorter pubescence at the base and longer towards the apex. In Telostylus, the arista is apically white, densely pubescent and, in Chaetonerius, it is usually subapically, brown and micropilose.

\section{Antennal base}

The absence of an antennal base has been historically used to associate the genera Telostylus and Chaetonerius (Aczél 1961) (Figs 6C, 7M). However, Sepúlveda et al. (2019) demonstrated that the species of Telostylus and Telostylinus have a shiny deflated antennal base with a characteristic membranous extension of the upper face dorsally (Figs 6A, 7L), which is absent in Teloneria (Figs 6B, E, 7N-O). Similarly, three other Oriental species of Chaetonerius present a distinctive yet incipient protruding antennal base (Fig. 6D, F): Chaetonerius comperei Cresson, 1926, Chaetonerius inermis (Schiner,

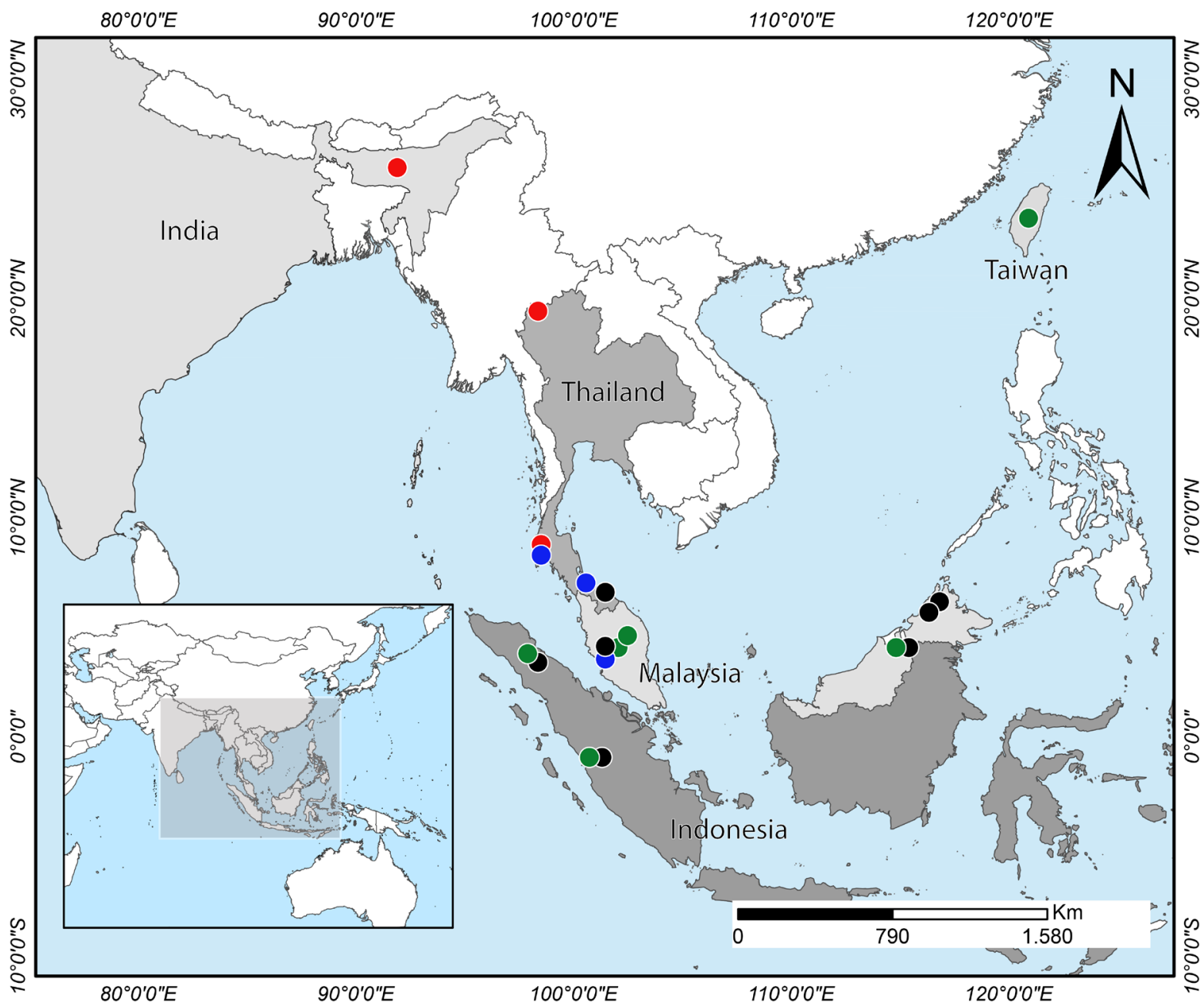

Fig. 9. Distribution of species of Teloneria Aczél, 1954. Conventions: Teloneria apicata (Edwards, 1919) comb. nov. (•); Teloneria bimaculata (Edwards, 1919) comb. nov. (•); Teloneria juceliae Sepúlveda \& Souza sp. nov. (•); Teloneria ladyae Sepúlveda \& Souza sp. nov. (•). 
1868) and Chaetonerius obscurus (Brunetti, 1913) (Sepúlveda \& de Carvalho 2019). In Teloneria, the antennal base is clearly well-developed and surrounds the antennal socket in all the extension of its circumference with clear limits (Fig. 6E), whereas, in Chaetonerius, the limits of the antennal base and upper face vanish in the inner margin (Fig. 6F).

\section{Inner process of pedicel}

The inner process of pedicel is a diagnostic character for Neriidae (Buck 2010) and the differences in its shape have been broadly used as diagnostic for generic identification (Aczél 1961; Buck 2010; Sepúlveda \& Souza 2020). Two main shapes have been described for Neotropical species of Neriidae: broad triangular, characteristic of Nerius Fabricius, 1805 (Fig. 7A) and narrow triangular to finger-like for the other genera (Fig. 7B-H). A third shape, broad linear and positioned on the dorsal half, was described for Telostylus (Sepúlveda et al. 2019) (Fig. 7I), and is similarly observed in the species of Teloneria (Fig. 7J-K).

\section{Fronto-orbital setae}

Species of Chaetonerius bear three equally spaced fronto-orbital setae (Figs 6F, 7M) and most of the Telostylus species lack anterior and middle fronto-orbital seta (Figs 6A, 7L) (only present in Telostylus decemnotatus Hendel, 1913). In both Chaetonerius and Telostylus, the posterior fronto-orbital seta is positioned at the level of the posterior third of the eye, whereas in Teloneria, it is positioned at the level of the mid length of the eye (Fig. 7N-O). Moreover, the middle fronto-orbital seta in Teloneria is positioned at the anterior third of the eye, near the anterior fronto-orbital seta, which is positioned almost at the level of the anterior margin of eye.

\section{Dorsocentral setae}

The number of dorsocentral setae is a taxonomically informative character for the determination of the genera in Neriidae (Aczél 1961; Sepúlveda \& Souza 2020). The presutural dorsocental seta is only present in Chaetonerius, Eoneria Aczél, 1951, Odontoloxozus Enderlein, 1922, Nipponerius Cresson, 1926, Protonerius de Meijere, 1924 and Stypocladius Enderlein, 1922, and the number of postsutural dorsocentral setae is accurately constant amongst the genera of Neriidae Cerantichir Enderlein, 1922, Glyphidops Enderlein, 1922, Gymnonerius Hendel, 1913, Longina Wiedemann, 1830, Loxozus Enderlein, 1922 (Fig. 8A), Nerius, Paranerius Bigot, 1883, Telostylinus and Telostylus (Fig. 8B) have 1 seta; Derocephalus Enderlein, 1922 (Fig. 8C), Nipponerius and Stypocladius have 2 setae; Chaetonerius (Fig. 8D) has 3 setae, except for Chaetonerius latifemur Enderlein, 1922, which has 2 setae (Fig. 8E); and Eoneria (Fig. 8F) and Protonerius have 4 setae.

The postsutural dorsocentral setae in Teloneria are constant in number, position and size, with one pair of very long setae positioned near the anterior and posterior margins of the postsutural scutum (Fig. 8G$\mathrm{H})$. These are different from the three equally spaced setae in Chaetonerius and the two prescutellar setae in C. latifemur, which likely represent a secondary loss within the genus. Likewise, the presutural dorsocentral seta, common in Chaetonerius and other genera with two or more postsutural setae, is also present in Teloneria. The position of this seta in Teloneria is only similarly found in Protonerius, being differently placed medially on the presutural scutum, when compared with other genera bearing this seta near the transverse suture.

Barraclough (1993) referred to the 'scapular seta' as a very small seta positioned just lateral to the dorsocentral line, at the anterior margin of the presutural scutum (Fig. 8D-E). This seta was described as a diagnostic character for Chaetonerius by Sepúlveda \& de Carvalho (2019) and for the Neotropical Cerantichir (Sepúlveda et al. 2013) and it is not known to be present in any other Oriental or AustralOceanic group of Neriidae. The scapular seta is also absent in Teloneria. 


\section{Wing}

Morphological similarities are evident among the species of Telostylus and Teloneria, such as the wing being distally infuscate (Fig. 8H-J). Notwithstanding, patterns of wing infuscation can be differentiated by the highly defined limits on Teloneria and the darker infuscation on the apex of cell r1 in Telostylus.

\section{Male genitalia}

The male genitalia of representatives of Telostylus are uniform and taxonomically uninformative (Sepúlveda et al. 2019), whereas in Chaetonerius, they are the most accurate source of information for the identification of many species (Barraclough 1993). The male genitalia of Teloneria are similar to those of Chaetonerius. Both genera have an elongate and cape-shaped sternite 6 and, in some cases, the cercus is very elongate and has dense setae. However, differently from Chaetonerius, the epandrium, cercus and surstylus in Teloneria do not present conspicuous transformations.

\section{Acknowledgments}

We are grateful to Daniel Whitmore, Amnon Freidberg, Steven L. Heydon and Joachim Ziegler for the loan of material. The authors of the new species, DSS. and TAS. want to extend special acknowledgment to their mothers Jucelia and Lady, who always supported and encouraged the development of their careers in entomology and, to them, they dedicate the names of the new species. This research was funded by Conselho Nacional de Desenvolvimento Científico e Tecnológico (CNPq), grant numbers 159771/2018-8 (TAS.); 309873/2016-9 (CJBC.); PQ307732/2015-0 (LM.) and Fundação Carlos Chagas Filho de Amparo à Pesquisa do Estado do Rio de Janeiro (FAPERJ), grant numbers E-26/202.381/2017 and E-26/202.382/2017 (DSS.).

\section{References}

Aczél M.L. 1954. Results of the Archbold Expeditions: Neriidae von Neuguinea (Diptera). Treubia 22: $505-531$.

Aczél M.L. 1955. Neriidae von Indonesien (Dipt. Acalyptratae). Treubia 23: 19-40.

Aczél M.L. 1961. A Revision of American Neriidae (Diptera, Acaliptratae). Studia Entomologica 4: 257-346.

Barraclough D.A. 1993. The southern African species of Neriidae (Diptera). Annals of the Natal Museum 34: 1-17.

Buck M. 2010. Neriidae. In: Brown B.V., Borkent A., Cumming J.M., Wood D.M., Woodley N.E. \& Zumbado M.A. (eds) Manual of Central American Diptera, Volume 2: 815-819. NRC Research Press, Ottawa.

Cumming J.M. \& Wood D.M. 2017. Adult morphology and terminology. In: Kirk-Spriggs A.H. \& Sinclair B.J. (eds) Manual of Afrotropical Diptera, Volume 1: 89-133. South African National Biodiversity Institute, Pretoria.

Edwards F.W. 1919. Results of an expedition to Korinchi Peak, Sumatra. Part III. Invertebrates. II. Diptera. Collected in Korinchi, West Sumatra by Messrs. H.C. Robinson and C. Boden Kloss. Journal of the Federated Malay States Museums 8: 7-59.

Enderlein G. 1922. Klassifikation der Micropeziden. Archiv für Naturgeschichte 88: 140-229.

Hennig W. 1937. Übersicht über die Arten der Neriiden und über die Zoogeographie dieser AcalyptratenGruppe (Diptera). Stettiner Entomologische Zeitung 98: 240-280. 
Mello R.L. \& Ziegler J. 2012. Catalogue of the type material of Neriidae (Diptera, Schizophora) in the collection of the Museum für Naturkunde Berlin, Germany. Deutsche Entomologische Zeitschrift 59: 147-163. https://doi.org/10.1002/mmnd.201200009

Ovtshinnikova O.G. \& Galinskaya T.V. 2017. The male abdominal, genital and pregenital sclerites and musculature in Neria commutata (Czerny, 1930) (Diptera, Micropezidae). Entomological Reviews 97: 282-287. https://doi.org/10.1134/S0013873817030022

QGIS Development Team. 2019. QGIS geographic information system. Open Source Geospatial Foundation Project. Available online: https://qgis.osgeo.org [accessed 31 Oct. 2019].

Sepúlveda T.A. \& de Carvalho C.J.B. 2019. Chaetonerius Hendel (Neriidae: Diptera) from the East African islands with description of four new species from Madagascar and the Comoros. Zootaxa 4567 (1): 130-146. https://doi.org/10.11646/zootaxa.4567.1.7

Sepúlveda T.A. \& Souza D.S. 2020. Taxonomy and phylogeny of the Eoneria-group (Diptera, Neriidae). Insect Systematics \& Evolution 51: 637-671. https://doi.org/10.1163/1876312X-00002305

Sepúlveda T.A., Pereira-Colavite A. \& de Carvalho C.J.B. 2013. Revision of the neotropical genus Cerantichir (Diptera: Neriidae) with new records and a key to species. Revista Colombiana de Entomologia 39: 125-131.

Sepúlveda T.A., Souza D.S., Gomes L.R.P., Fogaça J.M. \& de Carvalho C.J.B. 2019. The Neriidae (Diptera) of Southeast Asia: a taxonomic revision of the genus Telostylus. European Journal of Entomology 116: 281-301. https://doi.org/10.14411/eje.2019.032

Steyskal G.C. 1966. Notes on flies captured in treetops in Malaya (Diptera: Empididae, Neriidae, Platystomatidae, Sepsidae, Muscidae). Proceedings of the United States National Museum 120: 1-16. https://doi.org/10.5479/si.00963801.120-3562.1

Steyskal G.C. 1977. Family Neriidae. In: Delfinado M.D. \& Hardy D.E. (eds) A Catalog of the Diptera of the Oriental Region, Suborder Cyclorrapha (excluding Division Aschiza), Volume III: 8-11. University Press of Hawaii, Honolulu.

Van Steenis J. \& Hippa H. 2012. Revision and phylogeny of the Oriental hoverfly genus Korinchia Edwards (Diptera: Syrphidae). Tijdschrift Voor Entomologie 155: 209-268.

https://doi.org/10.1163/22119434-00002014

Manuscript received: 11 November 2019

Manuscript accepted: 17 July 2020

Published on: 28 September 2020

Topic editor: Nesrine Akkari

Desk editor: Marianne Salaün

Printed versions of all papers are also deposited in the libraries of the institutes that are members of the EJT consortium: Muséum national d'Histoire naturelle, Paris, France; Botanic Garden Meise, Belgium; Royal Museum for Central Africa, Tervuren, Belgium; Royal Belgian Institute of Natural Sciences, Brussels, Belgium; Natural History Museum of Denmark, Copenhagen, Denmark; Naturalis Biodiversity Center, Leiden, the Netherlands; Museo Nacional de Ciencias Naturales-CSIC, Madrid, Spain; Real Jardín Botánico de Madrid CSIC, Spain; Zoological Research Museum Alexander Koenig, Bonn, Germany; National Museum, Prague, Czech Republic. 